\title{
Gambaran Karies Gigi pada Penyandang Diabetes Melitus di Rumah Sakit Kalooran Amurang
}

\author{
${ }^{1}$ Falen V. Ampow \\ ${ }^{2}$ Damajanty H. C. Pangemanan \\ ${ }^{3}$ Pritartha S. Anindita
}

\author{
${ }^{1}$ Program Studi Pendidikan Dokter Gigi Fakultas Kedokteran \\ ${ }^{2}$ Bagian Fisiologi Fakultas Kedokteran \\ ${ }^{3}$ Bagian Ilmu Kesehatan Gigi Mulut Program Studi Pendidikan Dokter Gigi \\ Universitas Sam Ratulangi Manado \\ Email: valenveronicka@yahoo.com
}

\begin{abstract}
Dental caries is caused by certain bacteria that have acid-forming properties. Due to these bacteria, a low $\mathrm{pH}$ in the oral cavity is achieved which may cause slow enamel demineralization and form a ferocious focus. Diabetes mellitus (DM), a metabolic disorder characterized by hyperglycemia, is one of the predisposing factors of dental caries. This study was aimed to obtain the profile of dental caries in people with diabetes mellitus. This was a descriptive study with a cross sectional design. Subjects were diabetic patients at the Internal Medicine Department of Kalooran Hospital Amurang. There were 50 patients in this study obtained by using total sampling technique. Diabetic status was determined by using random blood glucose level (Perkeni 2011) meanwhile caries status was assessed by using DMF-T score. Data were processed by using SPSS and then were presented in tabular form. The results showed that very high caries index was found in $16.0 \%$ of subjects with good blood glucose control, $30.0 \%$ with moderate blood glucose control, and $36.0 \%$ with poor blood glucose control; the total number was $82.0 \%$ of subjects. Most subjects had diabetes for 5-10 years $(44.0 \%)$ with very high caries index $(40.0 \%)$. Conclusion: Most diabetic patients had very high caries index with the highest percentage in patients with DM for 5-10 years and in patients with poor blood glucose control.
\end{abstract}

Keywords: diabetes mellitus, blood glucose level, dental caries

\begin{abstract}
Abstrak: Karies gigi terjadi oleh karena bakteri-bakteri tertentu yang mempunyai sifat membentuk asam sehingga terjadi $\mathrm{pH}$ rendah yang dapat menyebabkan pelarutan mineral enamel secara perlahan dan membentuk fokus perlubangan. Diabetes melitus (DM) yang ditandai dengan keadaan hiperglikemia merupakan salah satu faktor predisposisi terjadinya karies. Penelitian ini bertujuan untuk mengetahui gambaran karies gigi pada penyandang DM. Jenis penelitian ialah deskriptif dengan desain potong lintang. Subjek penelitian ialah penyandang DM di Poliklinik Penyakit Dalam RS Kalooran Amurang yang berjumlah 50 orang, diambil dengan teknik total sampling. Status DM dinilai melalui kadar glukosa darah sewaktu (Perkeni 2011), sedangkan status karies dinilai menggunakan skor DMF-T. Data diolah menggunakan SPSS kemudian disajikan dalam bentuk tabel. Hasil penelitian mendapatkan kategori indeks karies sangat tinggi ditemukan pada 16,0\% subyek dengan kontrol gula darah baik, 30,0\% dengan kontrol gula darah sedang, dan 36,0\% dengan kontrol gula darah buruk; jumlah total $82,0 \%$ subyek. Subjek terbanyak ialah penyandang DM 5-10 tahun $(44,0 \%)$ dengan kategori indeks karies sangat tinggi (40,0\%). Simpulan: Sebagian besar penyandang DM memiliki kategori indeks karies sangat tinggi dengan persentase tertinggi pada penyandang DM 5-10 tahun dan penyandang DM dengan kontrol gula darah yang buruk.

Kata kunci: diabetes melitus, kadar gula darah, karies gigi
\end{abstract}


Perkembangan teknologi seiring dengan munculnya fenomena globalisasi telah menyebabkan banyak perubahan, salah satunya ialah perubahan gaya hidup (lifestyle) berupa perubahan pola makan. Pola makan di kota-kota telah bergeser dari pola makan tradisional yang mengandung banyak karbohidrat dan serat dari sayuran, ke pola makan kebarat-baratan dengan komposisi makanan yang terlalu banyak mengandung protein, lemak, gula, garam dan mengandung sedikit serat yang berakibat prevalensi penyakit meningkat salah satunya yaitu diabetes mellitus (DM). ${ }^{1}$

Diabetes melitus (DM) adalah gangguan metabolisme dengan karakteristik hiperglikemia yang terjadi karena gangguan sekresi insulin atau gangguan kerja dari insulin, atau keduanya. ${ }^{2}$ Badan Kesehatan Dunia (WHO) memrediksi kenaikan jumlah penyandang diabetes di Indonesia pada tahun 2030 akan mencapai sekitar 21,3 juta jiwa. Hasil Riset Kesehatan Dasar (RISKESDAS) tahun 2007 menunjukkan bahwa prevalensi DM di daerah urban Indonesia untuk usia di atas 15 tahun sebesar 5,7\%. ${ }^{2}$ Prevalensi DM terkait usia, meningkat dari 5,9\%-7,1\% (246-380 juta jiwa) di seluruh dunia pada kelompok usia 20-79 tahun yang kejadiannya meningkat $55 \%$. Prevalensi diabetes baik berdasarkan diagnosis maupun gejala, secara merata di tingkat provinsi Sulawesi Utara didapatkan angka lebih tinggi dari pada angka nasional. Penyakit ini tersebar di seluruh Kabupaten dan Kota di Sulawesi Utara, Prevalensi DM di Kabupaten Minahasa Selatan sebesar $0,8 \%{ }^{3}$ Seperti organ tubuh lainnya maka gigi dan mulut juga dapat mengalami kelainan akibat DM. ${ }^{4}$

Diabetes melitus merupakan salah satu faktor predisposisi terjadinya karies. Pada pasien DM lama yang tidak terkontrol berpengaruh pada karies gigi karena bertambahnya karbohidrat yang dapat difermentasikan di dalam saliva yang merupakan medium yang sesuai untuk pembentukan asam sehingga memudahkan terjadinya karies. ${ }^{4}$

Karies gigi terjadi oleh karena bakteribakteri tertentu yang mempunyai sifat membentuk asam. Keadaan $\mathrm{pH}$ rendah bisa menyebabkan pelarutan progresif mineral enamel secara perlahan dan membentuk fokus perlubangan. ${ }^{4}$ Berdasarkan hasil Riset Kesehatan Dasar (RISKESDAS) tahun 2007 prevalensi nasional karies aktif ialah 43,4\%. Indeks DMF-T secara nasional sebesar 4,85. Hal ini menunjukkan rerata kerusakan gigi pada penduduk Indonesia yaitu 5 buah gigi per orang. Di 14 provinsi didapatkan prevalensi karies aktif di atas prevalensi nasional, termasuk Sulawesi Utara. ${ }^{2}$

Penelitian ini bertujuan untuk mengetahui gambaran karies gigi pada penyandang DM di Rumah Sakit Kalooran Amurang.

\section{METODE PENELITIAN}

Jenis penelitian ini ialah deskriptif dengan desain potong lintang. Penelitian dilakukan di Klinik Interna Rumah Sakit Kalooran Amurang pada bulan Agustus 2017. Populasi penelitian ini ialah seluruh pasien diabetes melitus (DM) di Klinik Interna Rumah Sakit Kalooran Amurang pada bulan Agustus 2017 yang berjumlah 50 orang.

Pada survei awal di RS Kalooran Amurang telah dilakukan seleksi subjek penelitian sesuai kriteria inklusi dan eksklusi, dilengkapi dengan penandatanganan informed consent.

Analisis data dilakukan dengan menggunakan program komputer dan data disajikan dalam bentuk tabel kemudian dianalisis secara deskriptif.

\section{HASIL PENELITIAN}

Penelitian ini dilakukan di Rumah Sakit Kalooran Amurang yang terletak di Kelurahan Buyungon Kecamatan Amurang, Minahasa Selatan. Rumah sakit ini merupakan rumah sakit Yayasan Gereja GMIM. Penelitian dilakukan di Bagian Rawat Jalan Klinik Penyakit Dalam. Berdasarkan hasil penelitian didapatkan subjek penelitian sebanyak 50 pasien penyandang DM yang rawat jalan di Klinik Penyakit Dalam

Tabel 1 menunjukkan subjek penelitian terbanyak berusia 35-45 tahun yaitu 19 pa- 
sien $(38,0 \%)$, dan yang paling sedikit pada usia 17-25 tahun yaitu 1 pasien $(2,0 \%)$.

Tabel 2 menunjukkan bahwa sebagian besar penyandang DM selama 5-10 tahun (20 dari 22 penyandang) memiliki kategori indeks karies sangat tinggi dengan persentase tertinggi yaitu $40 \%$. Demikian pula pada penyandang DM $<5$ tahun dan $>10$ tahun, sebagian besar memiliki kategori indeks karies (DMF-T) sangat tinggi.

Tabel 3 menunjukkan bahwa sebagian besar penyandang DM baik dengan kontrol gula darah yang baik, sedang, maupun buruk memiliki kategori indeks karies sangat tinggi tetapi persentase tertinggi (36\%) didapatkan pada penyandang DM dengan kontrol gula darah yang buruk.

Tabel 1. Distribusi subjek penelitian berdasarkan usia dan jenis kelamin

\begin{tabular}{ccccccc}
\hline \multicolumn{3}{c}{ Karakteristik subyek penelitian } & \multicolumn{2}{c}{ Total } \\
$\begin{array}{c}\text { Usia } \\
\text { (tahun) }\end{array}$ & \multicolumn{2}{c}{ Laki-laki } & \multicolumn{2}{c}{ Penis kelamin } & \multicolumn{2}{c}{} \\
& $\mathrm{n}$ & $\%$ & $\mathrm{n}$ & $\%$ & $\mathrm{n}$ & $\%$ \\
\hline $17-25$ & 0 & 0,0 & 1 & 2,0 & 1 & 2,0 \\
$26-35$ & 1 & 2,0 & 3 & 6,0 & 4 & 8,0 \\
$35-45$ & 8 & 16,0 & 11 & 22,0 & 19 & 38,0 \\
$46-55$ & 3 & 6,0 & 9 & 18,0 & 11 & 22,0 \\
$56-65$ & 7 & 14,0 & 4 & 8,0 & 12 & 24,0 \\
$>65$ & 1 & 2,0 & 2 & 4,0 & 3 & 6,0 \\
Total & 20 & 40,0 & 30 & 60,0 & 50 & 100,0 \\
\hline
\end{tabular}

Tabel 2. Distribusi indeks karies (DMF-T) bedasarkan lamanya menyandang DM

\begin{tabular}{ccccccccc}
\hline Lamanya & \multicolumn{4}{c}{ Indeks karies DMF-T } & \multicolumn{3}{c}{ Total } \\
DM & \multicolumn{2}{c}{ Sedang } & \multicolumn{2}{c}{ Tinggi } & \multicolumn{2}{c}{ Sangat Tinggi } & & \\
(tahun) & $\mathrm{n}$ & $\%$ & $\mathrm{n}$ & $\%$ & $\mathrm{~N}$ & $\%$ & $\mathrm{n}$ & $\%$ \\
\hline$<5$ & 2 & 4,0 & 5 & 10,0 & $\mathbf{1 0}$ & $\mathbf{2 0 , 0}$ & 17 & 34,0 \\
$5-10$ & 0 & 0,0 & 2 & 4,0 & $\mathbf{2 0}$ & $\mathbf{4 0 , 0}$ & 22 & 44,0 \\
$>10$ & 0 & 0,0 & 0 & 0,0 & $\mathbf{1 1}$ & $\mathbf{2 2 , 0}$ & 11 & 22,0 \\
Total & 2 & 4,0 & 7 & 14,0 & 41 & 82,0 & 50 & 100,0 \\
\hline
\end{tabular}

Tabel 3. Distribusi indeks karies (DMF-T) bedasarkan kontrol gula darah

\begin{tabular}{ccccccccc}
\hline \multirow{2}{*}{$\begin{array}{c}\text { Kontrol } \\
\text { gula darah }\end{array}$} & \multicolumn{2}{c}{ Sedang } & \multicolumn{2}{c}{ Tinggi } & \multicolumn{2}{c}{ Sangat Tinggi } & \multicolumn{2}{c}{ Total } \\
& $\mathrm{n}$ & $\%$ & $\mathrm{n}$ & $\%$ & $\mathrm{~N}$ & $\%$ & $\mathrm{n}$ & $\%$ \\
\hline Baik & 2 & 4,0 & 3 & 6,0 & 8 & 16,0 & 13 & 26,0 \\
Sedang & 0 & 0,0 & 0 & 0,0 & 15 & 30,0 & 15 & 30,0 \\
Buruk & 0 & 0,0 & 4 & 8,0 & $\mathbf{1 8}$ & $\mathbf{3 6 , 0}$ & 22 & 44,0 \\
Total & 2 & 4,0 & 7 & 14,0 & 41 & 82,0 & 50 & 100,0 \\
\hline
\end{tabular}

\section{BAHASAN}

Telah dilakukan penelitian mengenai gambaran karies gigi pada penyandang DM di RS Kalooran Amurang. Seluruh subjek yang memenuhi kriteria diperiksa gula darah dan karies gigi. Subjek penelitian 
berjumlah 50 pasien; yang berjenis kelamin laki-laki berjumlah 20 orang $(40,0 \%)$ dan yang perempuan berjumlah 30 orang $(60,0 \%)$.

Berdasarkan usia, subjek terbanyak berusia 35-45 tahun (36,0\%). Kemenkes menghimbau masyarakat melakukan deteksi secara dini DM agar masyarakat bisa mendapatkan perawatan dini sehingga DM tidak berlanjut dengan komplikasi. Menurut Peningkatan risiko DM meningkat seiring dengan usia khususnya pada usia lebih dari 40 tahun karena pada usia tersebut mulai terjadi peningkatan intoleransi glukosa. Usia merupakan salah satu faktor risiko seseorang dapat mengalami DM, karena semakin bertambahnya usia maka individu tersebut akan semakin mengalami penurunan fungsi tubuh (degeneratif) termasuk organ pankreas yang menghasilkan hormon insulin. ${ }^{5}$

Sebagian besar subyek berjenis kelamin perempuan $(60,0 \%)$. Gaya hidup dan perilaku makan perempuan di era modern ini lebih ke arah hal yang serba instan dan jarang beraktivitas. Selain itu dari segi fisik, perempuan juga memiliki peluang peningkatan indeks masa tubuh yang lebih besar. Sindroma siklus bulanan (premenstrual syndrome) dan pascamenopause membuat distribusi lemak tubuh menjadi mudah terakumulasi di daerah abdomen (obesitas sentral) akibat proses hormonal sehingga meningkatkan risiko menyandang DM. ${ }^{6}$

Berdasarkan lamanya menyandang DM, sebagian besar subyek memiliki kategori indeks karies sangat tinggi dengan persentase tertinggi (40\%) pada penyandang DM 5-10 tahun. Selain itu, sebagian besar penyandang DM baik dengan kontrol gula darah yang baik, sedang, maupun buruk memiliki kategori indeks karies sangat tinggi (Tabel 3), tetapi persentase tertinggi $(36 \%)$ didapatkan pada penyandang DM dengan kontrol gula darah yang buruk.

Seseorang dengan DM lama yang tidak terkontrol berpeluang besar mengalami kerusakan gigi karena terjadi peningkatan kadar glukosa dalam cairan saliva.
Glukosa dalam saliva ini akan dimetabolisme oleh bakteri di rongga mulut yang menghasilkan asam dan menurunkan $\mathrm{pH}$ saliva. Bila $\mathrm{pH}$ saliva menjadi asam, maka terjadi peningkatan jumlah bakteri streptococcus dalam rongga mulut. Bakteri-bakteri ini kemudian menghasilkan zat-zat yang akan mempercepat proses demineralisasi email yang berakibat karies pada gigi. ${ }^{7}$

Pada penelitian ini juga didapatkan subjek penelitian yang terbanyak memiliki kadar gula darah buruk pada kategori indeks karies sangat tinggi $(36,0 \%)$, dan yang paling sedikit yaitu subjek penelitian yang memiliki kadar gula darah baik pada kategori sedang $(4,0 \%)$. Temuan penelitian ini mendukung teori yang menyatakan bahwa tingginya kejadian karies pada penyandang DM dikarenakan ketidakmampuan dalam pengendalian glukosa darah yang mengakibatkan tingginya kadar glukosa dalam saliva, terutama penyandang DM yang jarang atau bahkan tidak pernah ke dokter gigi untuk membersihkan debris atau sisa-sisa makanan yang menempel pada permukaan giginya. ${ }^{7}$ Sisa-sisa makanan yang menempel tersebut kemudian bercampur dengan bakteri yang ada di rongga mulut terutama Streptococcus yang menyebabkan terbentuknya plak tebal. Debris yang sudah bercampur dengan bakteri dan menimbulkan plak akan menu-runkan $\mathrm{pH}$ saliva. ${ }^{8}$ Hasil penelitian ini juga didukung oleh penelitian Iwanda dan $\mathrm{Titi}^{4}$ yang mendapatkan hubungan bermakna antara DM dan karies ditinjau dari lama menyandang DM dan kontrol kadar gula darah.

\section{SIMPULAN}

Berdasarkan hasil penelitian ini dapat disimpulkan bahwa sebagian besar penyandang diabetes melitus memiliki kategori indeks karies sangat tinggi dengan persentase tertinggi pada penyandang DM 5-10 tahun dan penyandang DM dengan kontrol gula darah yang buruk.

\section{SARAN}

Bagi petugas kesehatan di RS terkait, diharapkan lebih meningkatkan sosialisasi tentang karies gigi pada penyandang DM. 
Bagi masyarakat agar sedini mungkin memeriksakan kadar gula darah dan lebih meningkatkan pola hidup sehat agar gula darah bisa terkendali baik serta menjaga kebersihan gigi dan mulut. Juga diperlukan pemeriksaan gigi secara teratur ke dokter gigi, poliklonik maupun rumah sakit.

\section{DAFTAR PUSTAKA}

1. Nurul G. Identifikasi bakteri pada karies gigi penderita diabetes mellitus [Skripsi]. Makassar: Fakultas Kedokteran Gigi Universitas Hasanuddin; 2011.

2. Pengurus Besar Perkumpulan Endokrinologi Indonesia (PB PERKENI). Konsensus Pengelolaan dan Pencegahan diabetes melitus tipe 2 di Indonesia 2011.Jakarta, 2012; p. 1-4.

3. Badan Penelitian dan Pengembangan Kesehatan. Riset kesehatan dasar. Jakarta: Departemen Kesehatan Republik
Indonesia, 2013 [cited 2015 April 5].

4. Iwanda, Titi NR. Hubungan diabetes mellitus dengan karies gigi [Skripsi]. Semarang: Fakultas Kedokteran Universitas Diponegoro; 2013.

5. Sudoyo AW, Setiyohadi B, Alwi I, Simadibrata M, Setiati S, editors. Buku Ajar Ilmu Penyakit Dalam jilid II (5th ed). Jakarta: Interna Publishing, 2009.

6. Irawan, Dedi. Prevalensi dan faktor risiko kejadian diabetes melitus tipe 2 di daerah urban Indonesia (Analisa data sekunder Riskesdas 2007) [Tesis]. Jakarta: Universitas Indonesia; 2010.

7. Mark AG, Peter PT, Robert LH (University of Iowa). Dokter Keluarga (3rd ed). Jakarta: EGC, 2006.

8. Herni P. Hubungan antara penyakit diabetes melitus tak terkontrol dengan kerusakan gigi. [Artikel Ilmiah]. Surakarta; Universitas Sebelas Maret; 2009. 